料表面付近に加工硬化が起りやすくなるためである. $600^{\circ} \mathrm{C} お よ ひ ゙ 700^{\circ} \mathrm{C}$ では試験中に析出および加工硬化 がおこり材料が強化されるため長時間前時効処理はむし ろ疲労強度を低下させる傾向にある。またクリ一プ破断 と異なり疲労では精内破壊であるため疲労強度は冷間加 エにより著しく向上する。

終わりに，本実験の遂行にあたり種御配虑を頂いた

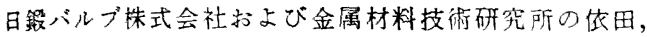
吉田，小池の各氏に深謝いたします。

\section{交 献}

1) P. M. Kelly and $J$. Nutting: High Strength Steels, BISRA Eng. Rep. Comm. Iron Steel Inst., Sp. Rep., No. 76 (1962)

2) V. F. ZACKAY: High-Strength Materials, (1964), p. 239, [Wiley]

$3)$ H. J. Harding and R.W.K. Honeycombe: J. Iron \& Steel Inst. (U.K.), 204 (1966), p.259

4) $N . J$. Grant, et al.: Trans. Amer. Soc. Metals, 48 (1956), p. 446

j) Frank $B$. Cuff, Jun., et al.: J. Iron \& Steel Inst. (U.K.), 186 (1957), p. 188

6) $R$. A. Lula, et al: Trans. Net. Soc, Amer. Inst. Min., Met. \& Pet Eng., 79 (1957), p.921

7 ) 織田, 片山, 小川, 満浦: 日本金属学会誌, 25 (1961)， p. 238

8 ) 織田, 吉井, 片山, 上原: 日本金属学会誌, 25 (1961), p. 241

9 ) 雀田, 撄井, 佐野, 川崎, 泉: 日本金属学会誌, 24 (1960), p. 645

\section{ボルトねじ部の単純引張り強さ*}

(ボルトの引張り強さについてーI )

東京蝲子製作所

遠藤健

Strength of Screw Thread of Bolts under Simple Tension

(On the tensile strength of bolts - I )

Ken FNDO

\section{1. 緒言}

ボルトに適当なナットをはめこのナットとボルトの 頭部をつかえで軸方向に引張ると普通はボルトのねじ部 で破断する。このときの破断荷重は一般に权じの谷径の 平滑試験片より大きく有効径のてれより小さいＪISな ど1)では, 故じの応力面積として谷径と有教径の平均 値を直径上する円定めている。乙かしボルトの処理条 件によつてはこの值を用いると同一条件で処理した平滑 試験片と破断応力が異なることが諗められる3゙. 无こで M6〜M12のボルトについていくつかの熱処理を施して 平滑部と权じ臂学破断し比較検討した。

\section{2. 実 験 方 法}

\section{$2 \cdot 1$ 試験片}

実験: 二用いたボルト試験片は機械搆造用の炭素鋼また は合金鋼製の6〜12 mmのメートル权じで各部寸注々化 学成分を Table 1 および 2 示す。これらの試験片は 摩き瑔招から頭部成形一权じ転造されたところを抜きと つたものである・バつに No 6 試騒片の材料から径か No 6 と等しくNo 6 の权じ断面と同じ断面形状の円

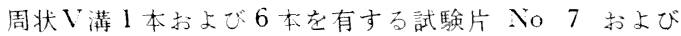
No 8 を作製した。この溝は丸捧を旋盤にくわ元必要な 断面形状汇研摩したバイトで削つたもりである。

$2 \cdot 2$ 熱処理

Table 1. Dimension of specimens.

\begin{tabular}{|c|c|c|c|c|c|c|c|c|}
\hline $\begin{array}{l}\text { Specimen } \\
\text { No }\end{array}$ & Screw & size & $\begin{array}{l}\text { Length } \\
(\mathrm{mm})\end{array}$ & $\begin{array}{l}\text { Shank } \\
\text { diameter } \\
(\mathrm{mm})\end{array}$ & $\begin{array}{l}\text { Effective } \\
\text { diameter } \\
(\mathrm{mm})\end{array}$ & $\begin{array}{l}\text { Minor diameter } \\
\qquad(\mathrm{mm})\end{array}$ & $\begin{array}{l}\text { Root radius } \\
\quad(\mathrm{mm})\end{array}$ & $\begin{array}{l}\text { Shank area } \\
\left(\mathrm{mm}^{2}\right)\end{array}$ \\
\hline 1 & 116 & $\mathrm{P} 1 \cdot 0$ & 58 & $5 \cdot 24$ & $5 \cdot 22$ & $4 \cdot 56$ & $0 \cdot 10$ & $21 \cdot 6$ \\
\hline 2 & M 6 & $\mathrm{P} 1 \cdot 0$ & 56 & $5 \cdot 23$ & $5 \cdot 23$ & $4 \cdot 55$ & $0 \cdot 10$ & $21 \cdot 5$ \\
\hline 3 & 118 & $\mathrm{Pl} 1 \cdot 25$ & 75 & $7 \cdot 06$ & $7 \cdot 06$ & $6 \cdot 21$ & $0 \cdot 10$ & $39 \cdot 2$ \\
\hline 4 & $M 10$ & $\mathrm{Pl} \cdot 5$ & 95 & $8 \cdot 90$ & $8 \cdot 90$ & $7 \cdot 88$ & $0 \cdot 11$ & $62 \cdot 2$ \\
\hline 5 & M10 & $\mathrm{P} 1 \cdot 25$ & 105 & $9 \cdot 06$ & $9 \cdot 06$ & $8 \cdot 22$ & $0 \cdot 10$ & $64 \cdot 5$ \\
\hline 6 & MII & $\mathrm{Pi} 5$ & 123 & $11 \cdot 87$ & $10 \cdot 97$ & $9 \cdot 96$ & 0.15 & $110 \cdot 7$ \\
\hline 7 & $12 \phi$ & P 1.5 & 120 & $11 \cdot 87$ & - & $9 \cdot 98$ & 0.13 & $110 \cdot 7$ \\
\hline 8 & $12 \phi$ & $\mathrm{P} 1.5$ & 120 & $11 \cdot 87$ & - & $9 \cdot 89$ & $0 \cdot 15$ & $110 \cdot 7$ \\
\hline
\end{tabular}

Table 2. Chemical composition of specimens. (\%)

\begin{tabular}{|c|c|c|c|c|c|c|c|c|c|}
\hline Specimen No & $\mathrm{C}$ & $\mathrm{Si}$ & $\mathrm{Mn}$ & $\mathrm{P}$ & $\mathrm{s}$ & $\mathrm{Cu}$ & $\mathrm{Ni}$ & $\mathrm{Cr}$ & Mo \\
\hline 1 & 0.35 & $0 \cdot 22$ & 0.60 & $0 \cdot 016$ & 0.023 & $0 \cdot 19$ & 0.05 & $0 \cdot 14$ & \\
\hline 2 & $0 \cdot 33$ & $0 \cdot 22$ & $0 \cdot 79$ & $0 \cdot 016$ & 0.016 & $0 \cdot 11$ & $0 \cdot 21$ & $1 \cdot 00$ & $0 \cdot 17$ \\
\hline 3 & 0.42 & 0.26 & $0 \cdot 69$ & $0 \cdot 017$ & 0.019 & $0 \cdot 20$ & 0.08 & 0.12 & \\
\hline 4 & 0.41 & 0.32 & 0.73 & $0 \cdot 019$ & $0 \cdot 022$ & 0.13 & 0.03 & $0 \cdot 10$ & \\
\hline 5 & 0.42 & $0 \cdot 23$ & 0.65 & $0 \cdot 016$ & $0 \cdot 023$ & $0 \cdot 16$ & 0.05 & $0 \cdot 13$ & \\
\hline $6,7,8$ & 0.40 & $0 \cdot 30$ & 0.81 & $0 \cdot 011$ & 0.010 & 0.15 & 0.47 & 0.50 & $0 \cdot 23$ \\
\hline
\end{tabular}

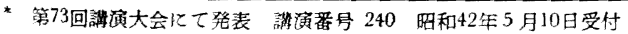


(A)

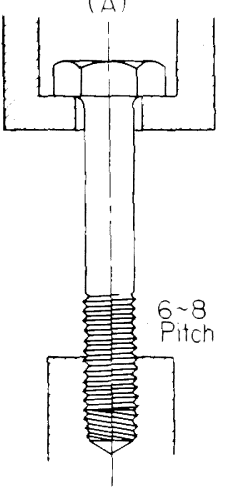

A : Thread portion test (left), B : Smooth portion test (right)

Fig. 1. Tension test method.

前項の試験片に低温の歪双とり焼鈍 2 種, 焼入焼居 6 種の処理を施した。烧鈍は $500^{\circ} \mathrm{C}$ おび $700^{\circ} \mathrm{C}$ の空気 中でそれぞれ $1 \mathrm{hr}$ 保持淩空泠した。焼入焼㞔は無酸化 中性の雾囲気中で $860^{\circ} \mathrm{C}$ 加熱 $30 \mathrm{~min}$ 保持, 油焼入乙 たのち200〜 700 C の空気中でそれでれ $1 \mathrm{hr}$ 保持後空

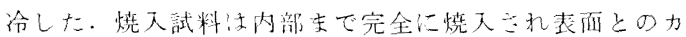
タサの差は認的られなかつた。

\section{$2 \cdot 3$ 引張試験}

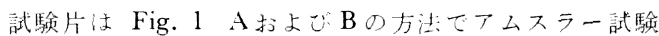
機にかけて二れれ゙れ权じ部と平滑部莸引張破断させた。 破断に要した時間は3〜10 minである。V 渄試験片は 普通に両端をつかえで引張つた。

\section{3. 実験結果とその考察}

\section{$3 \cdot 1$ 籍 I}

ホルト試娩片 No 4 の引張試験結果 Fig. 2 に示 す。グラフの左がわスケールが破断荷重でこれを平滑部 の訴面積で除した值を在がわに目盛つて亦る。平滑部の

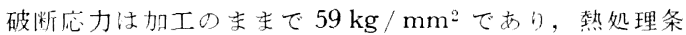

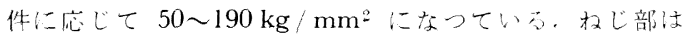
加工のままでは平滑部近い破断荷重を示吉が焼鈍, 焼

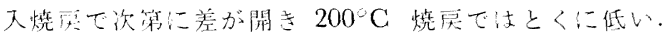
ほかのボルト試験片も同排な平滑部の応力とこれにたい する衫じ部の変化を示している。すへてのボルト試験片 について平滑部と权じ部の破断荷重の比を表したのが Fig. 3 である。ここで平滑部の径は有効径と等しく定め てあるから(No 6 のみ平滑径が太いので有効径に換算) この荷重比は有効径平滑試験片と权じ試験片の応力面積 の比を亦すことになる。ダラフの横蟿に平行な細線が有 效径面稆にたいするJISの枚じ応力面皘の比で，ぞの試

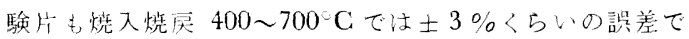
JIS に一致することがわかる。また加工のままや500 C 焼钝ではJIS上り大きく低温焼居のとくに太サイズでは JISより小さい。

ねじ部の軸に直角な断面は佩巻状を呈しその面棌はほ ほ有効径の断面秥に等しい。しかし䄈じ部の引張破断面 は Photo. 1 に見ら机るように大部分は谷底江沿って生 じどこかで㸚じ山を橫切つている。谷径の断面皘は有訤 径にくらべて $20 \%$ キ小さく，さらに权じ山1ケを横切

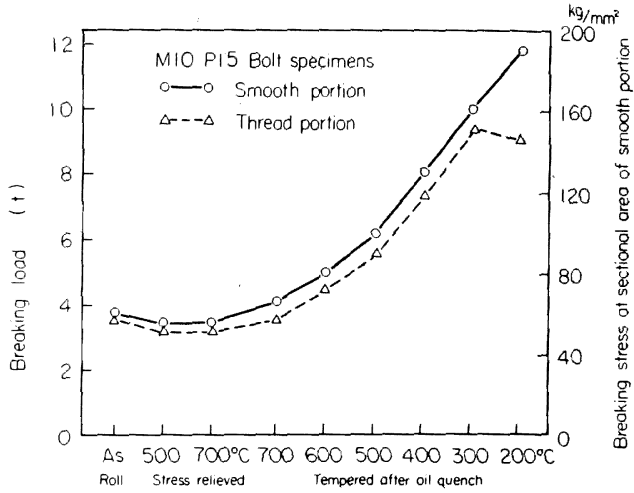

Fig. 2. Effect of heat treatment on tensile breaking load at the smooth and thread portion.

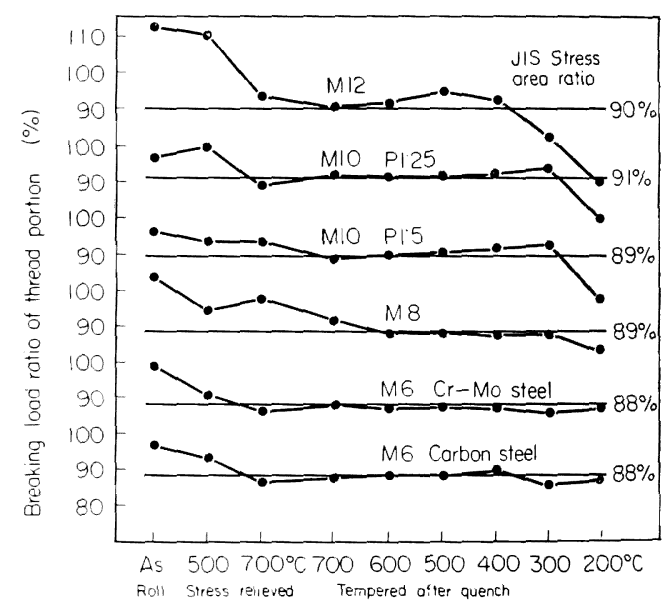

Fig. 3. Relationship between heat treatment and breaking load ratio of thread portion.

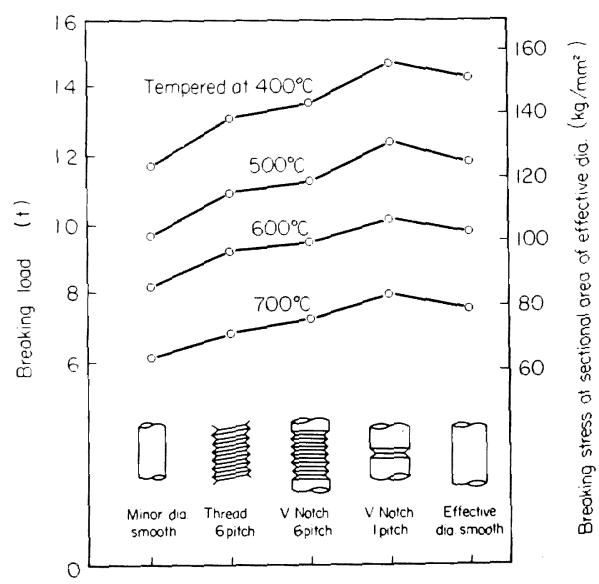

Fig. 4. Effect of shape of tension test specimens on M12 size, quenched and tempered. 


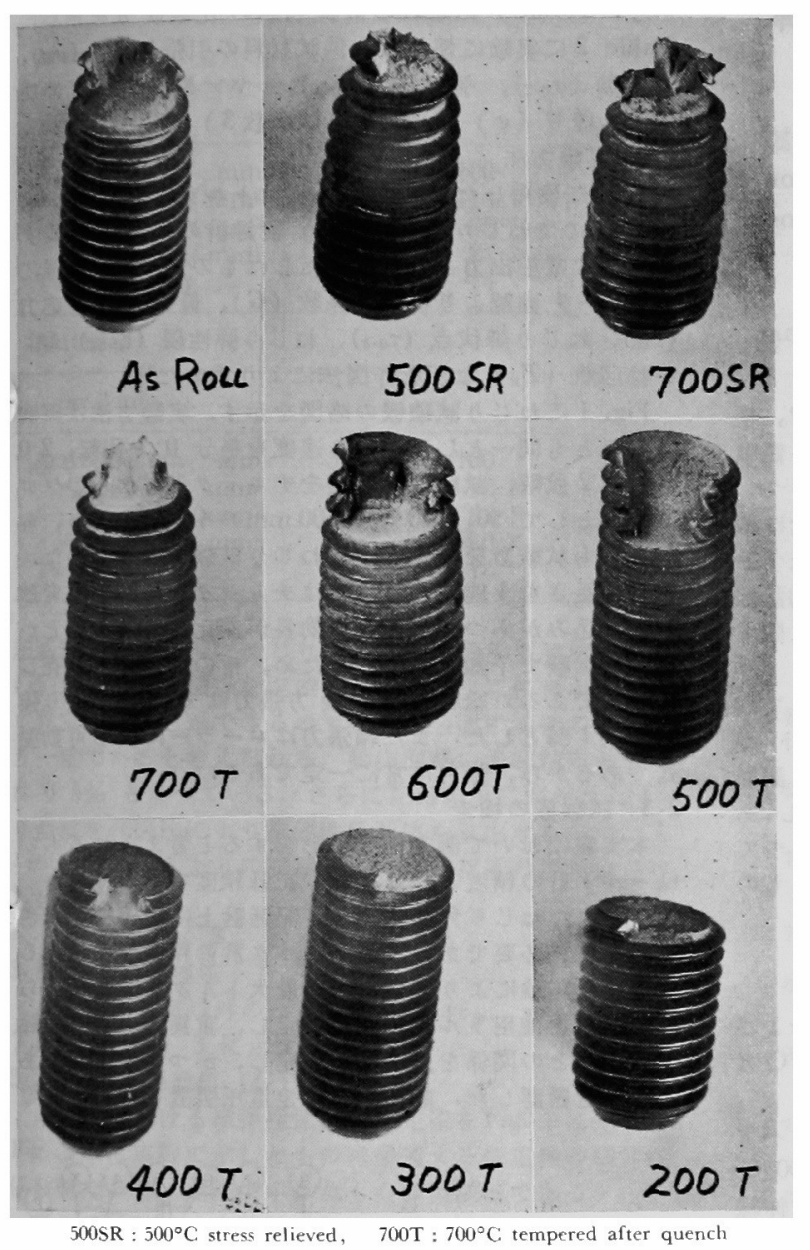

Photo. 1. Fracture of $\mathrm{M} 12$ bolt specimens.

Table 3. Breaking appearance of thread and notch.

\begin{tabular}{c|c|c}
\hline $\begin{array}{l}\text { Tempering } \\
\text { temperature }\end{array}$ & $\begin{array}{c}\text { No } 6 \\
\text { pitch thread }\end{array}$ & $\begin{array}{c}\text { No } 8 \\
\text { circular notchs }\end{array}$ \\
\hline $700^{\circ} \mathrm{C}$ & $\begin{array}{l}\text { Good elongation } \\
1 \text { thread break }\end{array}$ & $\begin{array}{l}\text { Good elongation } \\
1 \text { notch break }\end{array}$ \\
\hline $600^{\circ} \mathrm{C}$ & $\begin{array}{l}\text { Elongation } \\
5 \text { threads break }\end{array}$ & 6 notchs break \\
\hline $500^{\circ} \mathrm{C}$ & 7 threads break & 6 notchs break \\
\hline $400^{\circ} \mathrm{C}$ & 3 threads break & 3 notchs break \\
\hline
\end{tabular}

る面積は有効徍面積の約 $1.0 \%$ であるがこれを加えても

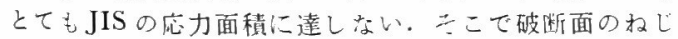
山横切りには関係ないのではないかと考えて第 2 の実験 老行放つた。

3.2 実殹 I
No 6 試験片の权し部と同じ断面形状の円周状 【湛を有する試験片 No 7 および No 8 をボ ルト試験片がうらに一致する範囲に処理して引張 破断させた。长の結果をNo 6 毛含的てFig. 4

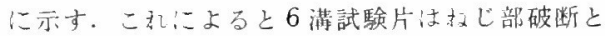
ほ济等しい荷重を示寸。破断面の状態をTable 3 のとおりかなり類似しており必ずしもなじ山を横 切つて破断しなくても谷径平滑試験片より強度が 高いことがわかる。これは枚じ山の存在が引張荷 重中の塑性变形を妨げ比較的に断面収箱の少ない 状態で加工硬化して破断するためであるう. そし て結果的: 応力面皘が有効径と谷径の中間になる のであろう、嗨が 1 本の場合に流有効径の平滑試 験片より強くさらに变形が難しくなつた結果在示 している、ボルトを引張試駼するさいナットを深 く杞これで引張られる机じ山数を減らすとてれ が十分ある場合よりも破断荷重が大く就ること はすでに経験上知られている。

Fig. 2 で加工のまままたは 500 - C 焼鈍の荷重 比が大きいのは权し転造による加工硬化が残つて いるためである。亦た低温焼㞔の荷重比が小さい のは延性の低下によつて切欠脆化が現われたもの である。一般に切欠荆は二の数を増すと応力集中

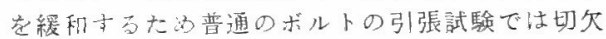

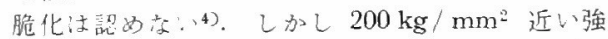
度では浮乞えど塑性変形を生じないため応力緩和 がなれないのであうう。

\section{4. 結言}

ピッチおよび鋼種ふ異なるもの在含む $0.4 \% \mathrm{C}$ 鋼のM6〜M12ボルトを起よ二50〜190 kg/ $\mathrm{mm}^{2}$ こ熱処理してねじ部の破断強度を平滑部と比較し た。寺けへつに M12 P1.5のねじ断面と同じ形 状の円周状、菶試験片を用いて破断状態を観察し た、云の結果つぎようなことがわかつた

(1) 焼入後 400 ～700 C 焼展では有効径平滑 試験片にないする玟じ部の応力面積の比はJISの

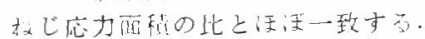

（2）JIS の応力面積が有効径と谷径の中間にあるの は故じ山の存在が引張荷重中の望性变形を妨引結果的: 荷重に対抗する面積が谷径面積より大きく少た放であ る。

（3）加工のまままた泜温焼鈍ては权じ転造による 加工硬化で見かけの応力面程: JISより大きく, 低温焼 戻のとくに太サイズのものでは切欠脆化を生じてJISよ り小さい.

1) JIS B, $1180(1965)$

2) S.AE J475 a Appendix E, (1966)

3 ) 上田, 田中: 材料, 15 (1966), p. 88

4) ヤタシェフ：权しの製造技術と斌じ各部の主要寸

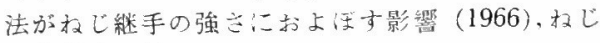
技術研究会訳 